\title{
Lenin's Utopianism: State and Revolution
}

General histories give little credence to the utopian side of Lenin's revolutionary thought, especially in relation to his only formal utopian work, State and Revolution. Most histories pass off that book as an "intellectual deviation" resulting from Lenin's "revolutionary fever" of 1917 or as a piece of political opportunism, while offering What Is To Be Done? as the statement of orthodox Leninism. In keeping with the tone of What Is To Be Done? Lenin is generally portrayed as the political realist par excellence, a pragmatist of the first order, a "hard-nosed" strategist confined by neither intellectual theories (not even Marxism) nor human emotions. This neat and simple formula is most convenient in attributing the success of the November Revolution to Lenin's talents for organization and political astuteness.

This one-dimensional interpretation of Lenin has been more or less accepted by most historians without serious question; there has been, consequently, little study of the relation of State and Revolution to Lenin's revolutionary thought. Robert $V$. Daniels has stated the standard evaluation of the work in his article "The State and Revolution: A Case Study in the Genesis and Transformation of Communist Ideology." He compares State and Revolution with What Is To Be Done?, pointing up the disparity between the ideas and the attitudes displayed in the two works. He first stresses the predominant position given to the party vis-à-vis the masses in What Is To $B e$ Done? and its essential role of revolutionary organization; to this he contrasts the minor role accorded the party and its organizational work in State and Revolution. That is, to prove the "uniqueness" of State and Revolution, Daniels shows how the work deviates from the ideas and attitudes expressed in What Is To Be Done?, which is supposed to represent the "true" Lenin or orthodox Leninism. It would then follow that since State and Revolution does not adhere to the concepts of What Is To Be Done?, it is obviously an aberration. ${ }^{1}$

Such a comparison misses much of the intent of State and Revolution. What Is To Be Done? is a practical, revolutionary guide designed as a blueprint to be applied to the Russian situation in 1902; State and Revolution is a theoretical work looking into the future, a sort of prophecy that attempts to

1. Robert V. Daniels, "The State and Revolution: A Case Study in the Genesis and Transformation of Communist Ideology," American Slavic and East European Revicw, 12, no. 1 (February 1953) : 22-43. 
depict the new socialist order, the future utopia. It was not intended by its author to be achieved in his own lifetime; it was a "revelation" for the next generation, for the generation that would wage the successful socialist revolution. It was, according to Trotsky, to be Lenin's "secret last will and testament."2

The general sympathy for Daniels's interpretation is quite understandable, since State and Revolution does appear, on the surface, to be completely antithetic to the spirit and program of most of Lenin's best-known works, and especially to the nature of his actual policies. One is immediately impressed in reading State and Revolution with the dominant role assigned to the proletarian masses, as opposed to the role of the party, in the coming revolution, and with its role in the process of constructing the new socialist society-with the emphasis on the spontaneous abilities of the working class and with the minimal attention given to organization and discipline. ${ }^{3}$ The hard-line elitist approach to revolution, which constitutes a major theme of What Is To Be Done? and is an essential element of Leninism, gives way to spontaneous, anarchistic tendencies in State and Revolution; careful planning and organizing by the vanguard gives way to impatient, idealistic improvisation. The proletariat is not only to assume direction of the revolution; it is also expected to transport Russia from a semifeudal agrarian society to a socialist society in one great sweep, a feat reminiscent of the narodnik schemes which envisioned by-passing the capitalist stage of economic development and moving directly to a socialist society. Whereas Lenin had argued earlier that full capitalist development must precede socialism and had branded the narodnik "leap across the centuries" as utopian, in State and Revolution he put forward his own utopian "leap" but tried to eliminate it from the ranks of utopian schemes by providing for a brief period of transition from capitalism to communism. $\mathrm{He}$ admitted that it would be impossible to destroy all officialdom at one blow-that would be utopian. But to break up the old bureaucratic machinery and replace it with a new and different apparatus, an apparatus that would gradually "wither away" as its functions were replaced by the "natural" cooperation of all members of society-that was not utopian (33:48-49).

Lenin's conception of the new society, of the "new age" as expressed in State and Revolution, was based in large part on Marx's historically dubious interpretation of the Paris Commune of 1871, found in Marx's Civil War in France. Marx described the ill-fated Commune as the "first manifestation of the real proletarian revolution." This description was essentially an idealized picture of the Communards smashing the old bureaucratic apparatus and re-

2. Leon Trotsky, The History of the Russian Revolution, trans. Max Eastman, 3 vols. (Ann Arbor, 1957), $3: 126$.

3. V. I. Lenin, Polnoe sobranie sochinenii, 5th ed. (Moscow, 1958-), 33:26. Subsequent references in the text will be to this edition. 
placing it with a new representative and democratic officialdom, an officialdom composed of working-class elements. The proletarian nature of the Commune government was to be ensured by direct democracy and the right of immediate recall. In a similar vein Lenin described the new society in State and Revolution as a universal bureaucracy in which the business of operating the state and the economy would be the task of every citizen. His defense of this anarchistic state of affairs was that the capitalist system had reduced the functions of state and economy to such simple operations of "registration, filing, and checking" that they could be performed by every literate citizen. Every citizen would thus be responsible for "running the state and the economy"; and he would perform these duties for "workingmen's wages." This universal bureaucracy would prevent the development of a professional, elitist bureaucratic system (33:43-44). It would be organized much like the postal system with a standard wage scale and would be under the control and direction of the "armed proletariat" (33:50).

The transition period between the old and the new bureaucratic systems would be devoted to suppressing the old exploiters and to destroying every remnant of the old state machinery. This initial phase of the transition would introduce the "first" or "lower" stage of Communist society. The lower stage would involve the abolition of the standing army, which would be replaced by the armed masses; the abolition of all private property, which would be replaced by the social ownership of all property and the means of economic production; the election of all "officials" by direct vote, subject to immediate recall.

The higher stage of Communist society would witness the "withering away of the state." In order to explain away the existence of the state in the new order, Lenin invoked Hegel's law of "transformation of quantity into quality." That is, capitalist democracy, which employed the state apparatus as a special instrument to suppress the masses of the people, would be transformed into "proletarian democracy," something that would no longer be a state "in the accepted sense of the word" (33:42). The lower stage of communism would not do away with all injustice and inequality, Lenin explained, but it would prevent human exploitation because all of the means of economic production would be held in common ownership by society. In fact, the lower stage of communism essentially amounted to the implementation of a complete socialist economy laced with a few anarchistic political decorations (33:93).

The higher stage of communism involved more than economics and politics; it was especially concerned with the social and psychological outlook of the population. This stage would be achieved only after the masses subordinated individual desires to the interests of the whole society, only after man's competitive instincts were transformed into a spirit of voluntary cooperation. When this stage of social harmony had been reached, society would 
witness the "withering away of the state," the "special functions of a special stratum" having become the everyday tasks of every citizen. The universal bureaucracy of bookkeepers, technicians, and managers would have become commonplace by this time. This was the stage at which every citizen would perform to the limits of his ability but receive merely according to his needs. Lenin sincerely believed that if man could become accustomed to observing what he termed the "fundamental rules of social life," then his labor would be so pleasant and productive that he would naturally work to the best of his capabilities without demanding personal material profit and that all social antagonism would consequently disappear. There would be such an abundance of goods within the economy that competition between individuals would be superfluous; everyone would have everything he would ever need. These citizens of the "new age" would naturally understand that profit was not a reward for individual talent but a reward for the general character of collective cooperation (33:96-97).

Such is the simplistic and utopian nature of State and Revolution. Yet regardless of how unrelated these naive notions might appear to be to Lenin's practical activities, it is quite amiss to neglect the work because it is "not serious." Such interpretations have resulted, at least in part, from the tendency of historians to associate State and Revolution with the Lenin of postMarch 1917, that is, with the period of Lenin's revolutionary career when he made a pronounced shift to the left in his revolutionary tactics and thought. It is practically beyond dispute that Lenin was considerably affected by the successes of the 1917 revolutions and that his political judgment during that year was more than a little determined by these events. Post-March 1917 and the early months of 1918 clearly represent a period when Lenin moved furthest from the attitudes that we generally describe as Leninist, from the attitudes of What Is To Be Done?

To classify State and Revolution as simply a product of this revolutionary period, which is the usual method of treating it, is to mistake its motivation and to suggest that it is "un-Leninist" and not to be taken seriously; it is to suggest that the work was written by a Lenin who was "inebriated by revolutionary fever." This chronology is not explicitly outlined, but is rather implied by historians who apparently have not considered it important to distinguish between when the work was researched and essentially completed and when it was written. Daniels, for example, says: "State and Revolution is a work conforming neither to Lenin's previous thought nor to his subsequent practice. It stands as a monument to its author's intellectual deviation during the year of revolution, 1917."' This statement implies that the work was conceived

4. R. N. Carew Hunt, The Theory and Practice of Communism (Baltimore, 1950), p. 171.

5. Daniels, "The State and Revolution," p. 22. 
during the revolutionary period; it ignores the fact that the book was essentially completed before the March Revolution, at a time when Lenin was very pessimistic about the prospects of a revolution in his own lifetime.

Louis Fischer has made the implication even more forceful: "Despite its plethora of Marx-Engels terminology and quotations, the Lenin book is an aberrant intellectual enterprise, a fanciful exercise for so rock-hard a man, as un-Leninist as the mask he wore and the false name he bore in hiding while writing it." If State and Revolution is included in the revolutionary period, a period during which Lenin did experience a decided shift to the left and during which the new Bolshevik government issued a number of anarchistic decrees, it is quite logical to interpret the book as either an emotionally charged intellectual aberration or a propaganda piece designed to gain popular support for the Bolshevik cause. If, however, the work is placed in its proper chronology-that is, before the March Revolution-it becomes apparent that the interpretations cited above are quite inadequate.

It is usually overlooked that Lenin put together the materials for State and Revolution during the months of December 1916 through February 1917. While engaged in his research he had no inkling that Russia was on the verge of revolution. The nation was, it is true, experiencing a number of strikes and riots due to the breakdown of transportation and the economy, but these complications were nothing new to the wobbling tsarist regime. Few of Russia's revolutionaries anticipated revolution in 1917, and Lenin was no exception. It is against this pessimistic background that the ideas and attitudes expressed in State and Revolution must be viewed, since the bulk of the notes used in the actual writing of the work (entitled "Marxism on the State") are dated January and February 1917 (33:306).

The fact that State and Revolution was essentially completed before the revolutionary period is substantiated by Lenin himself. A full month before he received the news of the March Revolution, he wrote to Alexandra Kollontai that he was "preparing (have almost got the material ready) an article on the question of the attitude of Marxism to the state" (49:388). The letter was dated February 17, 1917. The article was, of course, State and Revolution. It was not until a month after his letter to Kollontai that Lenin learned of the Revolution, at which time he put aside the manuscript and devoted all of his efforts to returning to Russia. It was another month before he was successful in reaching his native land. He had left the manuscript in Stockholm. After finally arriving in Russia, he was too absorbed with organizing the Bolsheviks and attacking the Provisional Government to concern himself with the book. Yet shortly after the July Demonstrations, which prompted the government to outlaw the Bolsheviks, Lenin wrote to L. B. Kamenev, "If they do me in, I ask you to publish my notebook: 'Marxism on the State' (it got left behind

6. Louis Fischer, The Life of Lenin (New York, 1964), p. 122. 
in Stockholm)... . I think that it could be published after a week's work" (48:444).

Lenin's letter to Kollontai in February noting that the work was almost completed, the ensuing months during which the manuscript remained in Stockholm, and Lenin's letter to Kamenev in July stating that the book could be put into shape for publication with a week's work all indicate that State and Revolution was essentially completed before Lenin learned of the March Revolution. It is therefore a distortion of facts to imply that the work is a product of Lenin's "revolutionary fever" during the months of revolution, and consequently an "intellectual deviation." His concern that the work be published even if he should be killed would also indicate that he considered it to be more than a mere piece of political propaganda.

If State and Revolution is divorced from the revolutionary period and viewed as a theoretical work written for the future, a work intended to be Lenin's "last will and testament," consisting of ideas which were formulated not in the heat of revolution but in the cool detachment of the Zurich Library, then there is sufficient reason to interpret it as representing an integral part of the whole of Lenin's revolutionary thought and personal make-up. The book may then be viewed as a serious revelation of the end to which Lenin had devoted his life.

Lenin's research into the nature of the future state undoubtedly helped him to clarify his own position on the subject. It would seem that he had always felt a sympathy for the ideas expounded in State and Revolution but had never really categorized them in his mind or tried to weave them into any sort of coherent system. This process of defining his vague feelings about the nature of the new society can be traced through his changing attitude toward Nikolai Bukharin and Karl Kautsky. Lenin in fact took up the question of the nature of the state in response to certain "anarchistic" and "reformist" articles concerned with that question. L. B. Kamenev noted in Leninskii sbornik that it was precisely because of Bukharin's article "Der imperialistische Raubstaat" that Lenin began writing State and Revolution. Yet the final product hardly mentions Bukharin but includes a full chapter of invective against Kautsky. In the process of defining his feelings about the new society Lenin discovered that his position was much closer to Bukharin's leftism than to Kautsky's more realistic and moderate position. In the letter to Kollontai mentioned above, Lenin wrote that he had "come to conclusions which are even sharper against Kautsky than against Bukharin" (49:388), and in a letter to Inessa Armand he wrote that he had arrived at conclusions "much more against Kautsky than against N. I. Bukharin (who, however, is not right all the same, though nearer to the truth than Kautsky)" (49:390).

Kautsky had raised some very disturbing questions about the nature of the future socialist state, especially concerning bureaucracy and centraliza- 
tion-two of the very points on which Lenin's theory of the new state later broke down. Kautsky's conclusions were nothing less than a refutation of violent revolution and of Lenin's belief that the new state would eliminate coercion and social antagonism. Kautsky argued that "never, under any condition" could a proletarian revolution destroy state power; the most that it could hope to accomplish would be to shift the forces of power within the state from the hands of the bourgeoisie to the hands of the proletariat. In applying this assessment to Germany, he urged the German Social Democratic Party to capture state power by gaining a majority in parliament and making parliament the head of the government.

Kautsky's analysis epitomized Marxist "revisionism," that "bourgeois illness" which Lenin considered the greatest threat to the revolution. As he became increasingly opposed to Kautsky's views, he drew closer to Bukharin's leftist position. What he had described as Bukharin's "exceptional stupidities" in December 1916 (49:340) had become "little mistakes" by February 1917 (49:391). In fact, by February 1917 Lenin was prepared to publish Bukharin's article, which he had previously rejected, along with his own article on the state (49:388).

This same shift of emphasis is revealed in Lenin's research notes on State and Revolution. His initial research in August 1916 was concerned solely with refuting Bukharin's article on the state. The title of the work then was "Notes on the Article of N. I. Bukharin 'On the Theory of the Imperialistic State" " (33:329). In December 1916 he was still concerned with answering Bukharin, his research at that time being entitled "Remarks on the Article of N. I. Bukharin 'The Imperialistic Robber State'" (33:331). But his comprehensive notebook, which formed the basis of the book State and Revolution and which was compiled in January and February 1917 as "Marxism on the State," not only omitted Bukharin from the title but also omitted any criticism of him from the text, substituting an attack on Kautsky instead.

This revision of notes occurred long before Lenin learned of the March Revolution. Other than this revealing change of emphasis, the work written in August and September of 1917 and published in 1918 as State and Revolution is essentially the same work that was compiled in January and February of 1917 as "Marxism on the State." That is to say that Lenin did not change his views on the nature of the new society in the final draft of the book even though the final product was written during the revolutionary period. Furthermore, it is obvious from his letters to Kollontai and Armand that he was not excited over some novel discovery in his research on the nature of the state; his

7. Volume 33. For an example of a comparison between Lenin's "prerevolutionary period" notes and the finished product see page 181 in "Marxism on the State" and page 89 in State and Revolution; also compare pages 173-87 of "Marxism on the State" and chapter 5 of State and Revolution. 
findings merely confirmed his ideas on the subject. The mention of his research in these letters is almost casual and would seem to indicate that the ideas expressed in State and Revolution were not strangers to his mind but were an integral part of his revolutionary outlook and had been vaguely formulated long before the eventful year of 1917 .

The utopian notions voiced in State and Revolution were neither new nor alien to Lenin's intellectual and emotional outlook. It did not require the revolutionary excitement of 1917 to inspire him to produce such a work. From the very beginnings of his conversion to the ranks of the revolutionaries he had contemplated nothing less than the complete transformation of Russian society and even of the world. That transformation was not to be limited to the political, social, and economic aspects of society but would also include the psychological outlook of mankind. That is what State and Revolution is about-the harmonious new age that would emerge after the existing artificial psychological outlook of man had been redirected and man had returned to his "natural" state of "observing the fundamental rules of society."

The means described by Lenin for achieving the new harmonious age, however, constitute something of a paradox not only in his revolutionary thought but also within his work State and Revolution. How can an orderly and effective society be constructed out of the anarchistic proposals suggested in State and Revolution-destruction of the state, abolition of the army and police, the affairs of the entire society and economy placed in the hands of the masses? This represented no paradox for Lenin. He believed, as did his predecessors Chernyshevsky 8 and Marx, that the state was actually the creator of anarchy and disorder, of "unnatural competition" and coercion, and that if the state and its exploitative economic system were destroyed, man would return to his "natural" inclinations of unselfish cooperation and voluntary social organization. Once man had returned to his natural state of observing the "fundamental rules" of social existence, there would be no functions left for the state to perform, no need for police, army, or government bureaucracy. The few national functions could be performed by all of the citizens working in harmony with one another and for the good of all (33:100-102). The General Will would reconcile any and all conflicts between the individual and society and between individuals.

The inspiration behind these utopian notions was not revolutionary emotionalism. These attitudes were always a part of Lenin's intellectual and emotional make-up. They seem to have emerged in some sort of concrete form with his study of Chernyshevsky's What Is To Be Done? around $1887^{\circ}$ and

8. Leopold H. Haimson, The Russian Marxists and the Origins of Bolshevism (Boston, 1955), pp. 98-100.

9. Ibid., p. 97; also Nikolay Valentinov, Encounters with Lenin (London, New York, and Toronto, 1968), pp. 63-76. 
to have developed with his study of Marxism. That inspiration received its fullest expression in State and Revolution, a work compiled in the sober confines of the Zurich Library. Rather than being the product of revolutionary optimism, the material in State and Revolution was put together at a time when Lenin doubted that his generation would live to witness the "decisive battles of this coming revolution." He believed that it would be the youth of that day who would wage the victorious proletarian revolution. This assessment was made by him on January 22, 1917, little more than a month before the March Revolution (30:328). And it was for the youth, for future generations, and "for the sake of his own inner confidence," 10 that Lenin was working over the problem of the nature of the new society.

The fact that State and Revolution is Lenin's only major utopian work makes it readily susceptible to charges of insincerity and deviation. Before 1917 he had been occupied almost exclusively with preparing the party and the proletariat for their roles in the "inevitable" revolution and especially with developing the effectiveness of the "vanguard." Even after the March Revolution he did not abandon these tasks, but he was not concerned with these efforts in State and Revolution, because that work did not apply to 1917. But even though it is Lenin's only formal work dealing with the nature of the new society, the ideas and attitudes contained in it may be found scattered throughout his earlier writings. The same unrestrained optimism and unbounded confidence in the inevitable development of proletarian class consciousness (that is, that the proletariat were instinctively Marxists) found in State and Revolution is quite in evidence in his What the "Friends of the People" Are and How They Fight the Social Democrats, published in 1894. Here can be found the same implicit faith in the innate intelligence and ability of the Russian worker and the same insistence that the revolution will not settle for a mere change in the political system but will bring about a complete regeneration of man. There is the same belief that the revolution will be a universal enterprise that will usher in a new historical era. The work also gives one something of the warm enthusiasm that Lenin felt for the "innocent," though duped, working masses: "When its [the working class] advanced representatives have mastered the ideas of scientific socialism, the idea of the historical role of the Russian worker, when these ideas become widespread, and when stable organizations are formed among the workers to transform the workers' present sporadic economic war into conscious class struggle-then the Russian WORKER, rising at the head of all the democratic elements, will overthrow absolutism and lead the RUSSIAN PROLETARIAT (side by side with the proletariat of ALL COUNTRIES) along the straight road of open political struggle to THE VICTORIOUS COMMUNIST REVOLUTION" (1:311-12).

10. Trotsky, History of the Russian Revolution, 3:126. 
Lenin takes this unbounded faith in the revolutionary energies and abilities of the masses so far as to defend the "peasant socialists" of the 1860 s and 1870 s against the attacks of the contemporary narodniki, who often ridiculed the idealism of the early socialists: "Faith in a special order, in the communal system of Russian life-hence faith in the possibility of a peasant socialist revolution - that is what inspired them and roused dozens and hundreds of people to wage a heroic struggle against the government. And you, you cannot reproach the Social Democrats with failing to appreciate the immense historical services of these, the finest people of their day, with failing to respect their memory profoundly. But I ask you, where is that faith now? It has vanished" (1:271). Vanished? It had apparently found new life in Lenin's revolutionary thought. In this instance he proudly acknowledged Russian Social Democracy's debt to the idealists of the 1860s and 1870 s and also anticipated his future tactical contribution to Marxism which would call for a revolutionary alliance between peasantry and proletariat.

This same idealism, these same utopian notions are also present in Lenin's work "To the Rural Poor," published in 1903, which likewise shows his early concern with the peasantry as a revolutionary force and as an important element in the new society. It may be instructive to compare "To the Rural Poor" with State and Revolution, noting especially the emphasis of both on primitive democracy, voluntary cooperation, and the absence of social antagonisms in the new society. From "To the Rural Poor":

When the working class has defeated the entire bourgeoisie, it will take the land away from the big proprietors and introduce cooperative farming on the big estates, so that the workers will farm the land together, in common, and freely elect delegates to manage the farms. They will have all kinds of labor-saving machines, and work in shifts for not more than eight (or even six) hours a day. ... There will then be no struggle for money between the big and the small farmer; there will be no working for hire for others; all workers will work for themselves, all improvements in methods of production and all machines will benefit the workers themselves and help to make their work easier, improve their standard of living.

\section{From State and Revolution:}

The state will be able to wither away completely when society adopts the rule: "From each according to his ability, to each according to his needs," that is, when people have become so accustomed to observing the fundamental rules of social intercourse and when their labor has become so productive that they will voluntarily work according to their ability. "The narrow horizon of bourgeois right," which compels one to calculate with the heartlessness of a Shylock whether one has worked half an hour more than somebody else, whether one is not getting less pay than somebody else-this narrow horizon will then be crossed. There will be no need for 
society, in distributing products, to regulate the quantity to be received by each; each will take freely "according to his needs."

(33:96-97)

So even in the 1890s and early 1900s, no less than in 1917, Lenin envisioned a society of voluntary toil and mutual self-sacrifice; even then he dreamed of a society free from social antagonism; even then he was concerned with ending the competitive struggle for wealth, with abolishing wage labor, and with creating a completely harmonious society, one in which the oppressive power of government would be unnecessary. He simply reiterated these ideals in State and Revolution when he wrote that in the new society men would voluntarily work to the best of their ability and receive according to their needs. "The suppression of the standing army, and the substitution for it of the armed people" in State and Revolution was advocated by the same Lenin who in 1903 demanded that "the standing army be abolished and that a militia be established in its stead, that all the people be armed" ( $7: 170)$. Yet no one has pointed to What the "Friends of the People" Are or "To the Rural Poor" as utopian works or intellectual deviations.

Why are these and many other of Lenin's writings which are based on the same utopian premises neglected in the treatment of his revolutionary thought? Do not the same elements of utopianism exist in the works cited above as are present in State and Revolution-those elements that have caused that work to be labeled an aberration? His belief in the innate intelligence of the masses, his idealization of the common man, and his conviction of the inevitable dawning of a new historical era of universal harmony are the basis of his entire revolutionary career and are the foundation upon which much of his writing rests. ${ }^{11}$

Errors of political judgment resulting from his utopianism are especially in evidence during the 1905 and 1917 revolutions, when Lenin astonished even some of his most loyal disciples with his radical pronouncements and tactics. ${ }^{12}$ During the 1905 Revolution he wrote that the working class "is free of the cowardice, the hypocritical half-heartedness that is characteristic of the bourgeoisie as a class" (10:344). He endowed the Russian worker with all the attributes characteristic of Chernyshevsky's "new people" who were supposed to herald the "new age": "Revolutions are the festivals of the oppressed and the exploited. At no other time are the masses of the people in a position to

11. "Nachalo revoliutsii v Rossii" ( $9: 204)$; "Revoliutsionnaia armiia $\mathbf{i}$ revoliutsionnoe pravitel'stvo" (10:344); "Dve taktiki Sotsial-Demokratii $\mathrm{v}$ demokraticheskoi revoliutsii" (11:103-4); "O reorganizatsii partii" (12:86); "Doklad o revoliutsii 1905 goda" (30:310-12) ; "O zadachakh proletariata v dannoi revoliutsii" (31:115); "Groziashchaia katastrofa i kak s nei borot'sia" (34:192-93); "Uderzhat li Bol'sheviki gosudarstvennuiu vlast' ?" (34:305-8); "Kak organizovat' sorevnovanie?" (35:200-203) ; "K naseleniiu" (35:66).

12. William Henry Chamberlin, The Russian Revolution, 2 vols. (New York, 1965), $1: 118-19$. 
come forward so actively as creators of a new social order as at a time of revolution. At such times the people are capable of performing miracles ..." (11:103).

In 1917 Lenin dated the political maturity of the Russian masses from the 1905 Revolution:

Prior to January 22, 1905, the revolutionary party of Russia consisted of a small group of people, and the reformists of those days ... derisively called us a "sect." ... Within a few months, however, the picture changed completely. The hundreds of revolutionary Social Democrats "suddenly" grew into thousands; the thousands became the leaders of between two and three million proletarians. The proletarian struggle produced widespread ferment, other revolutionary movements among the peasant masses, fifty to a hundred million strong; the peasant movement had its reverberations in the army and led to soldiers' revolts, to armed clashes between one section of the army and another. In this manner a colossal country, with a population of $130,000,000$, went into the revolution; in this way dormant Russia was transformed into a Russia of revolutionary proletariat and a revolutionary people.

(30:310-11)

The 1905 Revolution had accomplished, Lenin believed, what even Bolshevik leadership could not achieve with its agitation and propaganda and organization. The revolution had divested the masses of their false attachments and had revealed their "natural" inclinations toward Marxism. The masses had generated a "fighting energy a hundred times greater than in ordinary, peaceful times," an energy directed against capitalism and in favor of socialism (30:312).

The revolutions of 1905 and 1917 were potent stimulants to Lenin's optimism and confirmed his fundamental utopian notions. They justified the "hope and faith" that he had always had in the masses and supported his assumptions about the nature of mankind. He was more concerned with mass radicalism than he was with the "objective stages" of capitalist development or with any of the other Marxist requirements for revolution. This optimism in turn affected his political judgment and tactics-revealed in 1905 by his sudden demands for an open party including the masses of workers, and in 1917 by his anarchistic decrees which presupposed communism to be "just around the corner."

While it would certainly be a distortion to offer State and Revolution as the basic statement of Lenin's political philosophy, it would be equally erroneous to dismiss it as a "fanciful exercise," as erroneous as to dismiss the implications of What Is To Be Done? simply out of sympathy for the ideals of State and Revolution, as many of Lenin's followers and sympathizers did. State and Revolution does represent his fundamental philosophy of man, his inner convictions on human nature, his ideals for a more humane world. 